\title{
Streptozotocin-Induced Diabetes in the Chinese Hamster
}

\author{
Biochemical and Endocrine Disorders
}

\author{
A. Y. Chang, R. E. Noble, and B. M. Wyse \\ Diabetes and Atherosclerosis Research, The Upjohn Company, Kalamazoo, Michigan, USA
}

Summary. Streptozotocin treatment $(125 \mathrm{mg} / \mathrm{kg})$ in the Chinese hamster induced hyperglycaemia, hypoinsulinaemia, hyperglucagonaemia and changes in body, liver, pancreas, stomach, kidney and adipose tissue weights. The pancreatic reserves of insulin and glucagon in the diabetic animals were low, but stomach glucagon high. These animals showed high levels of phosphoenolpyruvate carboxykinase and low levels of glucokinase, hexokinase, isocitrate dehydrogenase and malic enzyme, but normal levels of pyruvate kinase in the liver. Increases in lactate dehydrogenase subunit $\mathbf{B}$ and isozymes 2,3 and 4 were also observed in the liver, but not in the epididymal fat pad, of the diabetic animals. NAcetyl- $\beta$-D-glucosaminidase was elevated in plasma, liver and heart, but not in the kidney of the treated animals. Renal $\alpha$-galactosidase and $\beta$ glucosidase were depressed, whereas $\beta$-galactosidase and $\alpha$-glucosidase remained essentially normal. These features indicated that there were considerable differences between the biochemical disorders associated with streptozotocin-diabetes in the Chinese hamster and the published observations in the rat.

Key words: Streptozotocin, Chinese hamster, glucagon, glycosidases, lactate dehydrogenase isozyme, insulin.

In recent years, streptozotocin has been the most widely used agent to induce diabetes in laboratory animals. Its diabetogenicity arises from its cytotoxic effect on pancreatic islet B-cells and B-cell necrosis has been consistently demonstrated in all species of animals rendered diabetic by streptozotocin [1]. Its effect on islet $A_{2}$-cells, however, appeared to vary between species. For instance, streptozotocin was shown to induce occasional necrosis in $\mathrm{A}_{2}$-cells of the Chinese hamster [2] and the rabbit [3], whereas it caused no change in pancreatic glucagon content in the rat [4] and led to predominance of $A_{2}$-cells in the guinea pig islets [5]. In view of the proposed involvement of pancreatic glucagon in the biochemical manifestations of diabetes [6], it is possible that related variations might be found in streptozotocin-induced diabetes among different species. Streptozotocin-diabetes in the rat has been studied extensively and its biochemical disorders include reciprocal changes in hepatic gluconeogenic and glycolytic enzymes [7], shift in adipose lactate dehydrogenase (LDH) (L-lactate: NAD oxidoreductase, EC 1.1.1.27) isozyme pattern [8, 9] and alterations of some $\beta$-glycosidases in the liver, kidney and plasma [10-12]. Knowledge about the properties of these biochemical entities in the streptozotocin-diabetic Chinese hamster, which in contrast to the diabetic rat develops necrosis of $A_{2}$-cells, is lacking. This study was thus undertaken to determine if dissimilar biochemical disorders occur in the streptozotocindiabetic Chinese hamster as compared to those reported in the streptozotocin-induced diabetic rat.

\section{Materials and Methods}

\section{Animals}

Male Chinese hamsters, 4 to 7 months old, were selected from the Upjohn colony $M$ line, which was a highly inbred non-diabetic line and had produced consistently aglycosuric offspring. After $20 \mathrm{~h}$ fasting the control animals were injected intraperitoneally with $10 \mathrm{ml} / \mathrm{kg}$ of $0.15 \mathrm{~mol} / \mathrm{l} \mathrm{NaCl}$, adjusted to $\mathrm{pH}$ 
4.0 with $0.05 \mathrm{~mol} / 1$ citric acid. The experimental animals received $125 \mathrm{mg} / \mathrm{kg}$ streptozotocin dissolved in the same acidified saline solution at $12.5 \mathrm{mg} / \mathrm{ml}$. They were allowed food and water ad libitum and sacrificed on the morning of the 14th or 42 nd day.

\section{Blood Samples}

The animals were bled from the orbital sinus and blood was collected into small test tubes containing $500 \mathrm{U}$ Trasylol ${ }^{\circledR}$ and $0.6 \mathrm{mg} \quad \mathrm{Na}_{2}$ EDTA [(ethylenedinitrilo) tetracetic acid, disodium salt] per $0.5 \mathrm{ml}$ of blood. A small portion was removed for sugar determination by the ferricyanide method on an Autoanalyzer [13], and plasma was collected by sedimentation at $4^{\circ} \mathrm{C}$. N-Acetyl- $\beta$-D-glucosaminidase was measured and the remaining plasma sample was kept at $-20^{\circ} \mathrm{C}$ for insulin and glucagon measurements $[14,15]$.

\section{Liver and Adipose Tissue Samples}

After exsanguination and decapitation, the tissues were removed in the following order: liver, epididymal fat pad (epididymis + adipose tissue), heart, kidney, pancreas and stomach. The epididymal fat pad and a large portion of the liver were rinsed in cold saline, blotted, weighed on an analytical balance and ground in a Potter-Elvejem homogenizer with a Teflon pestle in 2 volumes (tissue weight) of buffer containing $20 \mathrm{mmol} / 1$ tris $\cdot \mathrm{HCl}, 0.15 \mathrm{~mol} / 1$ $\mathrm{KCl}, 2 \mathrm{mmol} / 1 \mathrm{EDTA}, 0.5 \mathrm{mmol} / 1$ dithiothreitol, $\mathrm{pH}$ 8.0. After centrifugation at $140,000 \times \mathrm{g}$ for $1 \mathrm{~h}$, the liver supernatant was assayed for glucokinase (ATP: D-glucose-6-phosphotransferase, EC 2.7.1.2), hexokinase (ATP: D-hexose-6-phosphotransferase, EC 2.7.1.1) and PEP carboxykinase (GTP: oxaloacetate carboxylyase, EC 4.1.1.32) and the remains were frozen in small aliquots and assayed for other enzyme activities and LDH isozyme distribution in the next three days. All samples were frozen and thawed only once. The fat pad supernatant was frozen for LDH activity and isozyme pattern determinations.

\section{Liver, Kidney and Heart Samples}

The remaining portion of liver, kidney and heart were rinsed in saline, blotted, weighed and homogenized in a Polytron ${ }^{\circledR}$ homogenizer at a setting of 5 for $30 \mathrm{sec}$ in 9 volumes (tissue weight) of a chilled medium of $0.45 \mathrm{~mol} / 1$ sucrose, $0.68 \mathrm{mmol} / \mathrm{l}$ EDTA, $\mathrm{pH}$ 7.0. After centrifugation at 12,000 $\times \mathrm{g}$ for $20 \mathrm{~min}$, the supernatant was saved and the pellet washed once with $5 \mathrm{ml}$ of the same medium. The wash was discarded and the sediment was frozen in 9 volumes (tissue weight) of the medium in a dry ice-acetone bath, thawed at room temperature, repeated twice, and again homogenized. The supernatant and particulate fractions were kept at $-20^{\circ} \mathrm{C}$ and assayed for various glycosidases within a week.

\section{Pancreas and Stomach Samples}

The pancreas was frozen immediately and the stomach was opened, rinsed in saline, blotted and frozen. Later, they were weighed and insulin and glucagon were extracted by homogenization in acid alcohol $(750 \mathrm{ml}$ of ethanol, $250 \mathrm{ml}$ of water and $15 \mathrm{ml}$ of conc. $\mathrm{HCl}$ ). The homogenates were allowed to stand at $4^{\circ} \mathrm{C}$ for 24 to $48 \mathrm{~h}$ and centrifuged. The supernatants were neutralized with concentrated $\mathrm{NH}_{4} \mathrm{OH}$ and the final supernatants were assayed for insulin and glucagon after appropriate dilutions.

\section{Enzyme Assays}

PEP carboxykinase was assayed by $\mathrm{NaHCO}_{3}-{ }^{14} \mathrm{C}$ exchange method according to Wagle and Ashmore [16]. Glucokinase, hexokinase, pyruvate kinase (ATP: pyruvate phosphotransferase EC 2.7.1.40), $\mathrm{LDH}$ and protein concentration were determined as described previously [7]. Isocitrate dehydrogenase (Isocitrate: NADP oxidoreductase, EC 1.1.1.42) and malic enzyme (L-malate: NADP oxidoreductase EC 1.1.1.40) were assayed spectrophotometrically at $340 \mathrm{~nm}$ in reaction mixtures according to Khan with the omission of MTT-tetrazolium [3-(4,5-dimethyl thiazolyl-2)-2,5-diphenyl tetrazolium bromide] and phenazine methosulfate [17].

Glycosidases were assayed with p-nitrophenyl derivatives as substrates [18]. p-Nitrophenyl glycosides were dissolved in buffer $(0.1 \mathrm{~mol} / 1$ $\mathrm{Na}_{2} \mathrm{HPO}_{4}$ adjusted to desired $\mathrm{pH}$ with $0.05 \mathrm{~mol} / \mathrm{l}$ citric acid) at a concentration of $5.26 \mathrm{mmol} / \mathrm{l}$. $\mathrm{N}$-Acetyl- $\beta$-D-glucosaminidase and $\alpha$ - and $\beta$-galactosidase were assayed at $\mathrm{pH} 4.5, \alpha$-glucosidase at 6.5 and $\beta$-glucosidase at 5.5. The enzyme activities were determined from a linear time course in a reaction mixture containing $0.95 \mathrm{ml}$ substrates and $0.05 \mathrm{ml}$ appropriately diluted extracts. Reaction was terminated with $0.2 \mathrm{ml} 300 \mathrm{~g} / 1$ trichloroacetic acid and $0.2 \mathrm{ml} 5 \mathrm{~mol} / 1$ 2-amino-2-methylpropanediol was then added to the supernatant. The products were determined at $415 \mathrm{~nm}$ with p-nitro-phenol as standards.

All enzyme assays were run at $37^{\circ} \mathrm{C}$. 
Table 1. Body weight, tissue weight and protein concentrations in normal and streptozotocin-diabetic Chinese hamsters

\begin{tabular}{|c|c|c|c|c|c|c|c|}
\hline \multirow{2}{*}{\multicolumn{2}{|c|}{ Measurement }} & \multicolumn{3}{|c|}{2 weeks after streptozotocin } & \multicolumn{3}{|c|}{6 weeks after streptozotocin } \\
\hline & & Control (6) & Strep (8) & $\mathrm{P}$ & Control (6) & Strep (6) & $\mathbf{P}$ \\
\hline \multicolumn{2}{|c|}{$\begin{array}{l}\text { Total body wt. } g \\
\text { \% Body wt: }\end{array}$} & $25.3 \pm 1.5$ & $24.8 \pm 1.0$ & NS & $30.1 \pm 0.2$ & $26.5 \pm 05$ & $<0.001$ \\
\hline \multicolumn{2}{|l|}{ Liver } & $5.0 \pm 0.1$ & $6.1 \pm 0.2$ & $<0.005$ & $5.0 \pm 0.1$ & $6.2 \pm 0.2$ & $<0.001$ \\
\hline \multicolumn{2}{|l|}{ Pancreas } & $0.61 \pm 0.03$ & $0.72 \pm 0.01$ & $<0.05$ & $0.54 \pm 0.02$ & $0.81 \pm 0.08$ & $<0.01$ \\
\hline \multicolumn{2}{|l|}{ Stomach } & $0.89 \pm 0.02$ & $1.14 \pm 0.04$ & $<0.001$ & $0.85 \pm 0.02$ & $1.33 \pm 0.10$ & $<0.001$ \\
\hline \multicolumn{2}{|c|}{ Epidıdymal fat pad } & $4.1 \pm 0.4$ & $3.0 \pm 0.2$ & $<0.05$ & $4.7 \pm 0.2$ & $2.8 \pm 0.2$ & $<0.001$ \\
\hline \multicolumn{2}{|c|}{ Kidney } & $1.08 \pm 0.03$ & $1.69 \pm 0.06$ & $<0.001$ & $0.96 \pm 0.02$ & $2.20 \pm 0.32$ & $<0.005$ \\
\hline \multirow{2}{*}{\multicolumn{2}{|c|}{$\begin{array}{l}\text { Heart } \\
\text { Protein conc. mg/g tissue: }\end{array}$}} & $0.53 \pm 0.03$ & $0.52 \pm 0.01$ & NS & $0.44 \pm 0.01$ & $0.49 \pm 0.02$ & NS \\
\hline & & & & & & & \\
\hline \multirow[t]{2}{*}{ Liver } & Supernatant $^{\mathrm{a}}$ & $108 \pm 1$ & $104 \pm 3$ & NS & $129 \pm 2$ & $136 \pm 3$ & NS \\
\hline & Precipitate & $79 \pm 2$ & $89 \pm 2$ & $<0.001$ & $81 \pm 3$ & $93 \pm 4$ & $<0.05$ \\
\hline \multirow[t]{2}{*}{ Kidney } & Supernatant & $90 \pm 5$ & $75 \pm 2$ & $<005$ & $92 \pm 2$ & $85 \pm 3$ & $<0.05$ \\
\hline & Precipitate & $80 \pm 3$ & $86 \pm 2$ & NS & $90 \pm 3$ & $88 \pm 2$ & NS \\
\hline \multirow[t]{2}{*}{ Heart } & Supernatant & $43 \pm 2$ & $42 \pm 1$ & NS & $37 \pm 1$ & $37 \pm 1$ & NS \\
\hline & Precipitate & $119 \pm 5$ & $106 \pm 4$ & NS & $127 \pm 1$ & $123 \pm 3$ & NS \\
\hline $\begin{array}{l}\text { Epidid. } \\
\text { Fat Pad }\end{array}$ & Supernatant & $18 \pm 3$ & $27 \pm 1$ & $<0.05$ & $13 \pm 1$ & $18 \pm 1$ & $<0.001$ \\
\hline
\end{tabular}

a All supernatants were obtained after centrifugation at $12,000 \times \mathrm{g}$

Table 2. Blood sugar, insulın and glucagon levels in normal and streptozotocin-diabetıc Chinese hamsters ${ }^{\mathrm{a}}$

\begin{tabular}{|c|c|c|c|c|c|c|c|}
\hline \multirow[t]{2}{*}{ Measurement } & \multirow[t]{2}{*}{ Unit } & \multicolumn{3}{|c|}{2 weeks after streptozotocin } & \multicolumn{3}{|c|}{6 weeks after streptozotocin } \\
\hline & & Control (6) & Strep (8) & $\mathbf{P}$ & Control (6) & Strep (6) & $\mathrm{P}$ \\
\hline Blood sugar & $\mathrm{mg} / 100 \mathrm{ml}$ & $101 \pm 6$ & $416 \pm 14$ & $<0.001$ & $98 \pm 6$ & $423 \pm 43$ & $<0.001$ \\
\hline \multicolumn{8}{|l|}{ Plasma } \\
\hline Insulin & $\mu \mathrm{U} / \mathrm{ml}$ & $40 \pm 14$ & $0 \pm 0$ & $<0.001$ & $116 \pm 25$ & $0 \pm 0$ & $<0.001$ \\
\hline Glucagon & $\mathrm{pg} / \mathrm{ml}$ & $109 \pm 19$ & $212 \pm 9$ & $<0.001$ & $51 \pm 11$ & $216 \pm 37$ & $<0.01$ \\
\hline \multicolumn{8}{|l|}{ Pancreas } \\
\hline Insulin & $\mathrm{U} / \mathrm{g}$ tissue & $1.28 \pm 0.05$ & $0.02 \pm 0.00$ & $<0.001$ & $0.70 \pm 0.03$ & $0.03 \pm 0.005$ & $<0.001$ \\
\hline Glucagon & $\mu \mathrm{g} / \mathrm{g}$ tissue & $2.78 \pm 0.22$ & $0.31 \pm 0.05$ & $<0.001$ & $3.39 \pm 0.27$ & $0.61 \pm 0.10$ & $<0.001$ \\
\hline Stomach glucagon & $\mu \mathrm{g} / \mathrm{g}$ tissue & $0.012 \pm 0001$ & $0031 \pm 0003$ & $<0.001$ & $0022 \pm 0.004$ & $0.082 \pm 0.008$ & $<0.001$ \\
\hline
\end{tabular}

a Insulin and glucagon were measured by immunoassays using bovine insulin and porcine glucagon as standards

Table 3. Hepatic enzyme activities in normal and streptozotocindiabetic Chinese hamsters

\begin{tabular}{|c|c|c|c|}
\hline \multirow[t]{2}{*}{ Enzymes } & \multicolumn{3}{|c|}{6 weeks after streptozotocin } \\
\hline & Control (6) & Strep (6) & $\mathbf{P}$ \\
\hline Phosphoenolpyruvate & \multicolumn{3}{|c|}{ nmole/min/mg } \\
\hline carboxykinase & $9.7 \pm 02$ & $19.2 \pm 2.1$ & $<0.001$ \\
\hline Glucokınase & $13.7 \pm 0.9$ & $2.4 \pm 03$ & $<0.001$ \\
\hline Hexokinase & $12.3 \pm 0.6$ & $2.8 \pm 0.2$ & $<0.001$ \\
\hline Pyruvate kınase & $456 \pm 23$ & $385 \pm 26$ & NS \\
\hline Isocitrate dehydrogenase & $741 \pm 29$ & $617 \pm 24$ & $<0.01$ \\
\hline Malic enzyme & $161 \pm 24$ & $59 \pm 10$ & $<0005$ \\
\hline
\end{tabular}

\section{LDH Zymograms}

Electrophoresis was run in $5 \%$ polyacrylamide slab gel at $300 \mathrm{~V}$ and 200 pulses/sec for $45 \mathrm{~min}$ [19], after a pre-running period of $2 \mathrm{~h}$. The samples $(0.01 \mathrm{ml})$ contained tissue extracts, $400 \mathrm{~g} / 1$ sucrose and $10 \mathrm{mg} / \mathrm{ml}$ bromophenol blue in the proportion of $5: 10: 1$ for the liver and $2: 8: 1$ for the adipose tissue. The gels were stained for LDH [17] and the percent absorption of each isozyme band was quantitated on Quick Quant (Helena Lab.) after scan- 
ning. The activities of $\mathrm{LDH}$ subunits $\mathrm{A}$ and $\mathrm{B}$ were then calculated [8].

\section{Insulin and Glucagon Assays}

Plasma and pancreas and stomach extracts were measured for insulin [14] and glucagon [15] by immunoassays. The lower limits of these assays were $4 \mu \mathrm{U}$ and $8 \mathrm{pg}$ per sample for insulin and glucagon respectively. The standards for insulin were of bovine and for glucagon of porcine origins. The cross-reactivities of Chinese hamster insulin and glucagon to the antisera in our assays were similar to those of mouse and rat samples. Serial dilutions of Chinese hamster pancreatic extracts gave curves parallel to the bovine insulin or porcine glucagon standard curves.

\section{Materials}

${ }^{125}$-I-Insulin was purchased from Nuclear International Corp.; ${ }^{125}$ I-glucagon, Nuclear Medical Laboratory; beef insulin and porcine glucagon standards, Eli Lilly; glucagon antiserum $30 \mathrm{~K}$, University of Texas Southwestern Medical School. All substrates, cofactors and coupled enzymes in assays were purchased from Sigma.

All data were analyzed statistically with Student's t-test and are expressed as "mean \pm SEM" in all tables.

\section{Results}

\section{Tissues}

Table 1 summarizes the comparison of body and tissue weights and tissue protein concentrations in control and experimental animals. The decrease in body weights was not observed at two weeks after streptozotocin administration, but was evident in the group studied six weeks after the injection. Changes observed at the 14th day included enlarged liver, pancreas, stomach and kidney and dystrophic epididymal fat pad and the changes were more pronounced on the $42 \mathrm{nd}$ day. The heart weight, however, remained normal in both groups of experimental animals. The protein concentrations in most tissues were also normal, with some exceptions. The liver $12,000 \times \mathrm{g}$ particulate and adipose tissue $140,000 \times \mathrm{g}$ supernatant fractions showed increased protein content and kidney supernatants had less proteins in the diabetic animals; the differences were observed at both 14th and 42nd days.

\section{Insulin and Glucagon}

The experimental animals were severely hyperglycaemic, with blood sugar levels over $400 \mathrm{mg}$ / $100 \mathrm{ml}$ (Table 2). Plasma concentration of insulin was close to zero in these diabetic animals, whereas their plasma glucagon level was more than double that of the controls. Interestingly, pancreatic glucagon content was extremely low in these animals and their stomach glucagon level was three to four times that in the control animals (Table 2). The diabetic animals were also depleted of pancreatic insulin. These changes observed in the experimental animals were evident in both groups studied at 2 and 6 weeks after streptozotocin administration.

Day-to-day variation in insulin and glucagon immunoassays had been observed regularly in this laboratory and it contributed to the discrepancy in insulin and glucagon levels between animals in the control groups at 2 and 6 weeks after treatment. Assays on samples in a group, i. e. control and streptozotocin-injected animals either 2 or 6 weeks after injection, were always carried out in a single operation so that day-to-day variability could be avoided.

\section{Hepatic Gluconeogenic and Glycolytic Enzyme Activities}

At the 42 nd day after streptozotocin injection, the animals showed twice as much hepatic PEP carboxykinase as those injected with saline (Table 3). On the other hand, their hepatic glucokinase and hexokinase activities were about $1 / 5$ of those in the control animals. Surprisingly, the diabetic animals did not show significantly decreased levels of hepatic pyruvate kinase. Isocitrate dehydrogenase, however, was found to be slightly and significantly lowered and malic enzyme considerably depressed in the experimental animals (Table 3 ).

\section{LDH Activity and Isozyme Pattern}

LDH zymograms were scanned and analyzed in terms of isozyme distribution as shown in Table 4. The liver tissue of the diabetic animals showed a higher percentage of LDH- 3 and -4 and less of LDH-5 than the controls. The specific activities of $\mathrm{LDH}$ subunits $\mathrm{A}$ and $\mathrm{B}$ were then calculated from these data and the tissue LDH activity [8]. The diabetic animals showed significantly higher hepatic LDH-B activity than the control animals. Studies on adipose tissue, however, showed similar LDH activity and isozyme patterns for both diabetic and nondiabetic animals. Again, concordant data were obtained in the two groups studied at different time periods. 
Table 4. Tissue lactate dehydrogenase isozyme distribution in normal and streptozotocin-diabetic Chinese hamsters

\begin{tabular}{|c|c|c|c|c|c|c|c|}
\hline \multirow[t]{2}{*}{ Measurement } & & \multicolumn{3}{|c|}{2 weeks after streptozotocin } & \multicolumn{3}{|c|}{6 weeks after streptozotocin } \\
\hline & & Control (6) & Strep (8) & $\mathbf{P}$ & Control (6) & Strep (6) & $\mathbf{P}$ \\
\hline \multicolumn{8}{|l|}{ Liver tissue } \\
\hline \multirow[t]{5}{*}{$\%$ total activity: } & LDH-1 & 0 & 0 & NS & 0 & 0.9 & NS \\
\hline & LDH-2 & 0 & $0.7 \pm 0.5$ & NS & $1.0 \pm 0.4$ & $3.2 \pm 0.8$ & $<0.025$ \\
\hline & $\mathrm{LDH}-3$ & $0.8 \pm 0.3$ & $3.8 \pm 1.3$ & NS & $4.4 \pm 0.3$ & $9.4 \pm 1.5$ & $<0.01$ \\
\hline & LDH-4 & $11.8 \pm 0.7$ & $16.9 \pm 1.2$ & $<0.025$ & $14.6 \pm 0.6$ & $20.8 \pm 0.9$ & $<0.001$ \\
\hline & LDH-5 & $87.4 \pm 0.9$ & $78.5 \pm 2.8$ & $<0.025$ & $80.1 \pm 1.1$ & $65.7 \pm 3.1$ & $<0.001$ \\
\hline \multirow[t]{2}{*}{$\mu \mathrm{mole} / \mathrm{min} / \mathrm{mg}$ protein: } & LDH-A & $1.97 \pm 0.14$ & $1.81 \pm 0.13$ & NS & $2.26 \pm 0.17$ & $1.78 \pm 0.20$ & NS \\
\hline & LDH-B & $0.067 \pm 0.007$ & $0.13 \pm 0.02$ & $<0.01$ & $0.16 \pm 0.02$ & $0.24 \pm 0.03$ & $<0.05$ \\
\hline \multicolumn{8}{|l|}{ Epididymal fat pad } \\
\hline \multirow[t]{5}{*}{$\%$ total activity: } & LDH-1 & $7.4 \pm 0.4$ & $6.4 \pm 0.5$ & NS & $8.8 \pm 0.4$ & $8.4 \pm 0.6$ & NS \\
\hline & LDH-2 & $13.8 \pm 0.4$ & $13.7 \pm 0.4$ & NS & $14.8 \pm 0.3$ & $14.7 \pm 0.6$ & NS \\
\hline & LDH-3 & $19.2 \pm 0.6$ & $20.7 \pm 0.4$ & NS & $20.2 \pm 0.4$ & $20.1 \pm 0.7$ & NS \\
\hline & LDH-4 & $24.2 \pm 0.9$ & $25.7 \pm 0.3$ & NS & $22.5 \pm 0.7$ & $22.8 \pm 1.0$ & NS \\
\hline & LDH-5 & $35.3 \pm 1.9$ & $33.5 \pm 1.0$ & NS & $33.7 \pm 1.0$ & $34.0 \pm 2.5$ & NS \\
\hline \multirow[t]{2}{*}{$\mu \mathrm{mole} / \mathrm{min} / \mathrm{mg}$ protein: } & LDH-A & $0.44 \pm 0.04$ & $0.47 \pm 0.02$ & NS & $0.49 \pm 0.04$ & $0.53 \pm 0.07$ & NS \\
\hline & LDH-B & $0.22 \pm 0.01$ & $0.24 \pm 0.01$ & NS & $0.27 \pm 0.02$ & $0.28 \pm 0.03$ & NS \\
\hline
\end{tabular}

Table 5. $\mathrm{N}$-acetyl- $\beta$-D-glucosaminidase in plasma, liver, heart and kidney in normal and streptozotocin-diabetic Chinese hamsters

\begin{tabular}{|c|c|c|c|c|c|c|c|}
\hline \multirow[t]{2}{*}{ Tissue } & \multirow[t]{2}{*}{ Unit } & \multicolumn{3}{|c|}{2 weeks after streptozotocin } & \multicolumn{3}{|c|}{6 weeks after streptozotocin } \\
\hline & & Control (6) & Strep (8) & $\mathbf{P}$ & Control (6) & Strep (6) & $\mathbf{P}$ \\
\hline Plasma & $\mathrm{U}^{\mathrm{a} / \mathrm{ml}}$ & $63 \pm 3$ & $138 \pm 3$ & $<0.001$ & $57 \pm 2$ & $114 \pm 1$ & $<0.001$ \\
\hline Liver & $\mathrm{U} / \mathrm{g}$ tissue & $1343 \pm 56$ & $1960 \pm 87$ & $<0.001$ & $1483 \pm 31$ & $2317 \pm 189$ & $<0.001$ \\
\hline Supernatant $t^{b}$ & $\mathrm{U} / \mathrm{mg}$ prot. & $4.3 \pm 0.3$ & $81 \pm 0.8$ & $<0.005$ & $3.2 \pm 0.2$ & $6.9 \pm 1.3$ & $<0.025$ \\
\hline Precipitate & $\mathrm{U} / \mathrm{mg}$ prot. & $11.1 \pm 0.6$ & $12.7 \pm 0.4$ & $<0.05$ & $13.2 \pm 0.3$ & $14.8 \pm 0.4$ & $<0.01$ \\
\hline Heart & $\mathrm{U} / \mathrm{g}$ tissue & $765 \pm 39$ & $802 \pm 54$ & NS & $636 \pm 18$ & $759 \pm 41$ & $<0.025$ \\
\hline Supernatant & $\mathrm{U} / \mathrm{mg}$ prot. & $5.6 \pm 0.2$ & $6.0 \pm 03$ & NS & $5.0 \pm 0.2$ & $5.2 \pm 0.3$ & NS \\
\hline Precipitate & $\mathrm{U} / \mathrm{mg}$ prot. & $4.4 \pm 0.1$ & $51 \pm 020$ & $<0.025$ & $3.6 \pm 0.1$ & $4.6 \pm 0.3$ & $<0.025$ \\
\hline Kidney & $\mathrm{U} / \mathrm{g}$ tissue & $4220 \pm 252$ & $3411 \pm 135$ & $<0.025$ & $4629 \pm 138$ & $4547 \pm 109$ & NS \\
\hline Supernatant & $\mathrm{U} / \mathrm{mg}$ prot. & $16.3 \pm 0.8$ & $13.5 \pm 0.9$ & $<0.05$ & $11.9 \pm 0.8$ & $10.7 \pm 0.6$ & NS \\
\hline Precipitate & $\mathrm{U} / \mathrm{mg}$ prot. & $34.6 \pm 0.9$ & $30.2 \pm 1.2$ & $<0.025$ & $39.6 \pm 2.0$ & $41.6 \pm 1.8$ & NS \\
\hline
\end{tabular}

a nmole substrate turnover per min

b Supernatants obtained after centrifugation at $12,000 \times \mathrm{g}$

Table 6. Renal galactosidases and glucosidases in normal and streptozotocin-diabetic Chinese hamsters

\begin{tabular}{|c|c|c|c|c|c|c|c|}
\hline \multirow[t]{2}{*}{ Enzyme } & \multirow[t]{2}{*}{ Unit } & \multicolumn{3}{|c|}{2 weeks after streptozotocin } & \multicolumn{3}{|c|}{6 weeks after streptozotocin } \\
\hline & & Control (6) & Strep (8) & $\mathbf{P}$ & Control (6) & Strep (6) & $\mathbf{P}$ \\
\hline$\alpha$-galactosidase & $\mathrm{U}^{\mathrm{a} / \mathrm{g} \text { tissue }}$ & $1537 \pm 190$ & $965 \pm 57$ & $<0.025$ & $1001 \pm 47$ & $766 \pm 37$ & $<0005$ \\
\hline Supernatant $t^{b}$ & $\mathrm{U} / \mathrm{mg}$ prot. & $9.9 \pm 0.7$ & $8.0 \pm 0.6$ & $<0.05$ & $4.5 \pm 0.5$ & $3.0 \pm 0.2$ & $<0.025$ \\
\hline Precipitate & $\mathrm{U} / \mathrm{mg}$ prot. & $63 \pm 0.2$ & $4.9 \pm 0.3$ & $<0.005$ & $6.6 \pm 0.4$ & $5.8 \pm 0.4$ & NS \\
\hline$\beta$-galactosidase & $\mathrm{U} / \mathrm{g}$ tissue & $2125 \pm 266$ & $1850 \pm 106$ & NS & $1942 \pm 57$ & $1770 \pm 74$ & NS \\
\hline Supernatant & $\mathrm{U} / \mathrm{mg}$ prot. & $14.2 \pm 1.2$ & $12.8 \pm 1.3$ & NS & $8.2 \pm 0.6$ & $6.7 \pm 0.5$ & NS \\
\hline Precipitate & $\mathrm{U} / \mathrm{mg}$ prot. & $10.6 \pm 06$ & $10.8 \pm 0.5$ & NS & $13.2 \pm 0.3$ & $13.8 \pm 0.8$ & NS \\
\hline$\alpha$-glucosidase & $\mathrm{U} / \mathrm{g}$ tissue & $147 \pm 9$ & $131 \pm 3$ & NS & $122 \pm 5$ & $108 \pm 7$ & NS \\
\hline Supernatant & $\mathrm{U} / \mathrm{mg}$ prot. & $1.1 \pm 0.0$ & $11 \pm 0.0$ & NS & $0.8 \pm 0.1$ & $0.7 \pm 0.1$ & NS \\
\hline Precipitate & $\mathrm{U} / \mathrm{mg}$ prot. & $0.6 \pm 0.0$ & $0.6 \pm 0.0$ & NS & $0.6 \pm 0.0$ & $0.5 \pm 0.0$ & NS \\
\hline$\beta$-glucosidase & $\mathrm{U} / \mathrm{g}$ tissue & $1111 \pm 12$ & $812 \pm 34$ & $<0.001$ & $1004 \pm 58$ & $676 \pm 60$ & $<0005$ \\
\hline Supernatant & $\mathrm{U} / \mathrm{mg}$ prot. & $119 \pm 05$ & $10.1 \pm 0.3$ & $<0.025$ & $10.5 \pm 0.5$ & $7.6 \pm 0.5$ & $<0.005$ \\
\hline Precipitate & $\mathrm{U} / \mathrm{mg}$ prot. & $0.8 \pm 01$ & $0.6 \pm 0.0$ & $<0.005$ & $0.4 \pm 00$ & $0.4 \pm 0.0$ & NS \\
\hline
\end{tabular}

a nmole substrate turnover per min

b Supernatants obtained after centrifugation at $12,000 \times \mathrm{g}$ 


\section{$N$-Acetyl- $\beta$-D-Glucosaminidase}

The plasma level of $\mathrm{N}$-acetyl- $\beta$-D-glucosaminidase in the diabetic animals was over twice as much as the control values (Table 5). Elevations of this enzyme in the experimental animals were also observed in liver and heart; in the liver excessive increase was more evident in the $12,000 \times \mathrm{g}$ supernatant fraction, whereas in the heart the moderate increase was found only in the particulate fraction. The kidney, on the contrary, showed depressed activity of this enzyme in the streptozotocin-treated animals two weeks afterwards, and on the 42nd day its level returned to normal.

\section{Renal Galactosidases and Glucosidases}

The diabetic animals had a decreased level of $\alpha$-galactosidase and $\beta$-glucosidase in the kidney and the decrease was more consistent in the supernatant fraction (Table 6). $\beta$-galactosidase and $\alpha$-glucosidase, on the other hand, were not significantly different between the diabetic and control animals in both groups studied at 2 and 6 weeks after streptozotocin treatment. The renal content of these glycosidases followed this order: $\beta$-galactosidase $>\alpha$-galactosidase $>\beta$-glucosidase $>\alpha$-glucosidase.

\section{Discussion}

The purpose of this investigation was to determine if biochemical and endocrine disorders in the streptozotocin-diabetic Chinese hamster were similar to those reported in the rat $[4,7-12]$. Our data demonstrated substantial differences between streptozotocin-diabetes in these two species of animals.

Our data on the depletion of both insulin and glucagon in the pancreas of the diabetic animal was consistent with the observation that streptozotocin induced necrosis of islet $\mathrm{B}$ - and $\mathrm{A}_{2}$-cells in the Chinese hamster [2]. We have further demonstrated in the diabetic animal an excessive level of immunoreactive glucagon-like substances in the stomach, which certainly contributed to the elevated level of plasma glucagon as reported here. The increase in stomach immunoreactive glucagon most likely resulted from the depletion of pancreatic insulin and glucagon, rather than from the direct action of streptozotocin. Changes in the levels of pancreatic insulin and plasma and stomach glucagon, similar to those found in streptozotocin-diabetes, have also been observed in some highly inbred sublines of hereditary diabetic Chinese hamster (unpublished observation). In view of the fact that some discordant features between streptozotocin-diabetes in the Chinese hamster and the rat had been reported to be glucagon- or cAMP-dependent, [8, 20,21] elucidation of the biological and chemical characteristics of the extrapancreatic immunoreactive glucagon-like substances might give us clues to the cause of the species-dependent discrepancy. In the dog, at least, it has been shown that immuno-equivalent amounts of pancreatic and gastric fundic glucagons were not bioequivalent in their glycogenolytic and adenylate cyclase-stimulating activities [22].

The streptozotocin-diabetic rat had increased hepatic gluconeogenic and decreased glycolytic enzymes [7]. In streptozotocin-diabetic Chinese hamster liver, PEP carboxykinase, the most insulin-dependent gluconeogenic enzyme, was elevated and glucokinase, the most insulin-sensitive glycolytic enzyme, depressed. Hexokinase, measured in the $140,000 \times \mathrm{g}$ liver supernatant, was also decreased in these animals. In rat liver cytoplasm, hexokinase existed mainly in type I form, which was reported to be insulin-insensitive [23]. Thus the observed depression in soluble hexokinase in streptozotocindiabetic Chinese hamsters warrants investigation of the electrophoretic property of the hepatic glucosephosphorylating enzymes in these animals. Likewise, a better understanding of the isozymic pattern of hepatic pyruvate kinase would also help us to explain the lack of significant depression of its activity in the diabetic Chinese hamster. Cytoplasmic malic enzyme and isocitrate dehydrogenase, which had been shown to be insulin-dependent $[24,25]$, were depressed in the diabetic Chinese hamster liver; changes in their levels correlated with the depletion of insulin in these animals.

Discrepancy between streptozotocin-induced diabetes in the Chinese hamster and the rat was also observed in the adipose LDH isozyme distribution. In the diabetic rat, a substantial increase in subunit $B$, as reflected in the elevations of LDH- 1 and -2 and the reductions of LDH-3, -4 and -5 , was found in the adipose tissue [8]. The diabetic Chinese hamster had normal LDH subunit activities and isozyme distribution in the epididymal fat pad, unlike the diabetic rat. On the other hand, increased LDH-B was observed in the liver tissue of the diabetic Chinese hamster, akin to the deviations found in the adipose tissue of the diabetic rat. It is speculated that the shift in LDH isozymes from A to B is to divert the carbon source to the gluconeogenic pathway in the event of increased lipid and glycogen 
breakdowns and decreased pyruvate oxidation due to insulin deficiency, since LDH-B is inhibited by high concentration of pyruvate [26]. Such a shift would prevent the inordinate accumulation of tissue lactate. The data thus suggest that $\mathrm{LDH}$ isozyme pattern shifts in the diabetic rat adipose tissue and the diabetic Chinese hamster liver were caused by similar factor(s), the effects of which, however, were not manifested in the adipose tissue of the Chinese hamster. The nature of the causative factor(s) and the cause for the observed discrepancy remain unknown.

In the streptozotocin-diabetic rat, Fushimi and Tarui reported reductions in renal $\mathrm{N}$-acetyl- $\beta$-Dglucosaminidase and normal levels of renal $\beta$-glucosidase and liver $\mathrm{N}$-acetyl- $\beta$ - $\mathrm{D}$-glucosaminidase [10-12]. In their studies, they only measured enzyme activities in the $10,000 \times \mathrm{g}$ supernatant of tissue extracts and claimed little activity remaining in the precipitates. We, however, observed substantial activities of these glycosidases in the residues and, therefore, measured them in both supernatant and particulate fractions. Our results indicated considerable discordance in the effects of streptozotocindiabetes on the levels of these enzymes between the Chinese hamster and the rat. In the Chinese hamster rendered diabetic by streptozotocin, normal levels of renal $\mathrm{N}$-acetyl- $\beta$-D-glucosaminidase and $\beta$-galactosidase, but reduced renal $\beta$-glucosidase and elevated liver $\mathrm{N}$-acetyl- $\beta$-D-glucosaminidase, were found. The only concordant feature in glycosidase levels between the streptozotocin-diabetic rat and Chinese hamster was elevation in serum $\mathrm{N}$-acetyl$\beta$-D-glucosaminidase. In the diabetic Chinese hamster a moderate increase in heart $\mathrm{N}$-acetyl- $\beta$-Dglucosaminidase was also observed. Furthermore, renal $\alpha$-galactosidase was significantly decreased, whereas renal $\alpha$-glucosidase remained essentially normal in these animals. Interestingly, in Chinese hamsters with hereditary diabetes, depression in $\alpha$-galactosidase and a normal level of $\alpha$-glucosidase were also found (our unpublished results). How significant a role the levels of these glycosidases play in glycoprotein turnover is unclear and its effect on the development of diabetic complications deserves further investigations.

\section{References}

1. Dulın, W.E, Soret, M. G Chemically and hormonally induced diabetes. In: B Volk (ed.). The diabetic pancreas. New York: Plenum Press (in press)
2. Wilander, E., Boquist, L.: Streptozotocin-diabetes in the Chinese hamster. Blood glucose and structural changes during the first $24 \mathrm{~h}$. Horm. Metab. Res. 4, 426-433 (1972)

3. Lazarus, S. S., Shapiro, S. H.: Streptozotocin-induced diabetes and islet cell alterations in rabbits. Diabetes 21, 129-137 (1972)

4. Pagliara, A.S., Stillings, S.N., Haymond, M. W., Hover, B.A., Matchinsky, F. M.: Insulin and glucose as modulators of the aminoacid-induced glucagon release in the isolated pancreas of alloxan and streptozotocin diabetic rats. J. Clin. Invest. 55, 244-255 (1975)

5. Petersson, B., Hellerström, C., Gunnarsson, R.: Structure and metabolism of the pancreatic islets in streptozotocin treated guinea pig. Horm. Metab. Res. 2, 313-317 (1970)

6. Unger, R.H., Orci, L.: Physiology and pathophysiology of glucagon. Physiol. Rev. 56, 778-826 (1976)

7. Chang, A.Y., Schneider, D. I.: Hepatic enzyme activities in streptozotocin-diabetic rats before and after insulin treatment. Diabetes 20, 71-77 (1971)

8. Chang, A.Y., Rothrock, D.: The effects of diabetes and insulin on adipose lactate dehydrogenase isozyme. Can. J. Biochem. 55, 113-116 (1977)

9. Hern, E. P., Schultz, J., O'Dorisio, M.S., Moore, R. O., Serif, G.S.: The effects of fasting, diabetes and hypophysectomy on adipose lactic dehydrogenase isozymes. Arch. Biochem. Biophys. 169, 331-338 (1975)

10. Fushimi, H., Tarui, S.: Kidney and serum $\beta$-N-acetylglucosaminidase activities in streptozotocin diabetic rats and their responses to insulin and glucagon. J. Biochem. (Tokyo) 76, 225-227 (1974)

11. Fushimi, H., Tarui, S.. $\beta$-glycosidases and diabetic microangiopathy. I. Decreases of $\beta$-glycosidase activities in drabetic rat kidney. J. Biochem. (Tokyo) 79, 265-270 (1976)

12. Fushımi, H., Tarui, S.: $\beta$-glycosidases and diabetic microangiopathy. II. An insulin-dependent isozyme of $\beta$-N-acetylglucosaminidase. J. Biochem. (Tokyo) 79, 271-275 (1976)

13. Gerritsen, G.C., Dulin, W. E.. Effect of a new hypoglycemic agent, 3,5-dimethylpyrazole, on carbohydrate and free fatty acid metabolism. Diabetes 14, 507-515 (1965)

14. Zaharto, D S., Beck, L.V · Studies of a simplifıed plasma insulin immunoassay using cellulose powder. Diabetes 17, 444-457 (1968)

15. Faloona, G. R., Unger, R.H.: Glucagon. In: B M. Jaffe, H. R. Behram (eds.): Methods of hormone radioimmunoassay, pp. 317-330. New York: Academic Press Inc. 1974

16. Wagle, S. R., Ashmore, J.: Studıes on carbon dioxıde fixatıon in normal and alloxan-diabetic animals. Biochim. Biophys. Acta 74, 564-565 (1963)

17. Khan, $\mathrm{P} \mathrm{M} \cdot$ Enzyme electrophoresis on cellulose acetate gel: zymogram patterns in man-mouse and man-Chinese hamster somatic cell hybrids. Arch. Biochem. Biophys. 145, 470-483 (1971)

18. Felton, J., Meisler, M., Pargen, K.. A locus determining $\beta$-galactosidase activity in the mouse. J. Biol. Chem. 249, 3267-3272 (1974)

19. Davis, B. J.. Disc electrophoresis. II. Method and application to human serum proteins. Ann. N.Y. Acad. Sc1. 121, 404-427 (1964)

20 Feliu, J.E., Hue, L., Hers, H. G · Hormonal control of pyruvate kinase activity and of gluconeogenesis in isolated hepatocytes. Proc. Natl Acad. Sci. USA 73, 2762-2766 (1976)

21. Blair, J.B., Cimbala, M. A., Foster, J L., Morgan, R A · Hepatic pyruvate kinase. Regulation by glucagon, cyclic 
adenosine $3^{\prime}: 5^{\prime}$-monophosphate and insulin in the perfused rat liver. J. Biol. Chem. 251, 3756-3762 (1976)

22. Srikant, C. B., McCorkle, K., Unger, R. H.: Properties of immunoreactive glucagon fractions of canine stomach and pancreas. J. Biol. Chem. 252, 1847-1851 (1977)

23. Katzen, H.M.: The multiple forms of mammalian hexokinase and their significance to the action of insulin. Adv. Enzyme Regul. 5, 335-356 (1967)

24. Goodridge, A.G., Adelman, T.G.: Regulation of malic enzyme synthesis by insulin, triodothyronine and glucagon in liver cells in culture. J. Biol. Chem. 251, 3027-3032 (1976)

25. Cuestas, R., Dixit, P. K.: Citrate metabolic enzymes in alloxan diabetes. Proc. Soc. Exp. Biol. Med. 142, 889-895 (1973)
26. Stambaugh, R., Post, D.: Effect of tissue extracts and temperature on lactate dehydrogenase isozymes. Biochim. Biophys. Acta 122, 541-543 (1966)

Received: March 31, 1977, and in revised form:

June 13, 1977

Dr. A. Y. Chang

Diabetes and Atherosclerosis Research

The Upjohn Company

Kalamazoo, MI 49001

USA 